\title{
Sheep husbandry in Southwestern Spain
}

\author{
TOBIAS PLIENINGER AND CLAUDIA WILBRAND
}

\section{$\mathrm{L}$} ow-intensity agricultural systems have formed large parts of Europe's landscape over centuries, but are nowadays facing an economic crisis. So does sheep husbandry that has traditionally been the predominant land use in Southwestern Spain. Long-term livestock grazing in this area has created a pattern of scattered holm and cork oak trees that is called dehesas (Figure 1). The dehesas

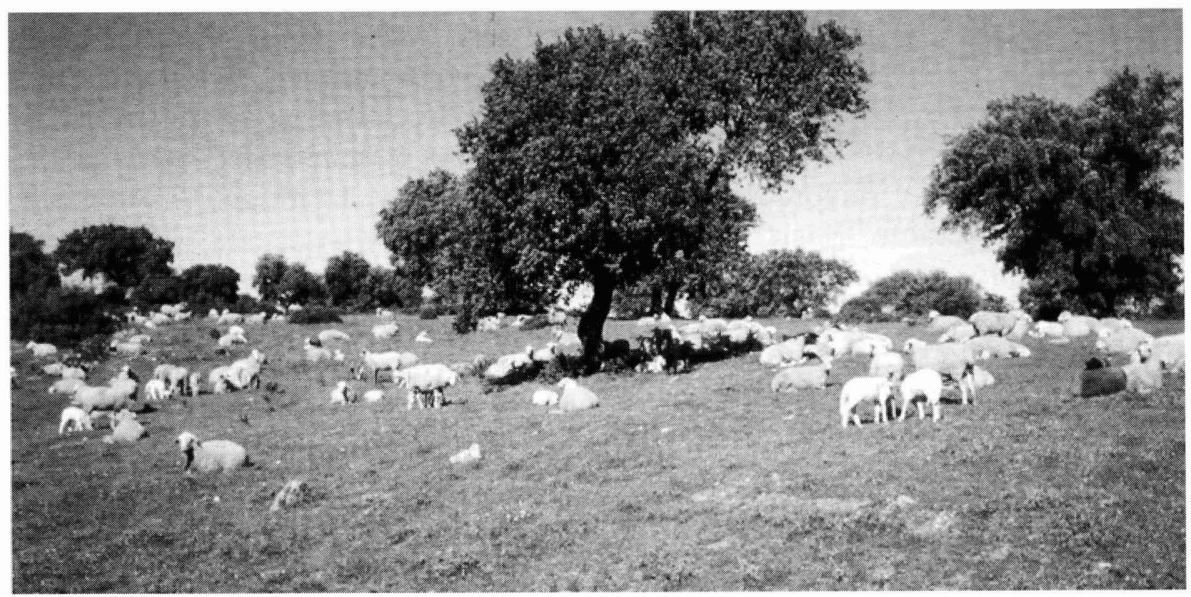

Fig. 1. Typical dehesa in Cuatro Lugares.

are considered to be of international importance for biological conservation: they are one of the few agroforestry systems remaining in Europe, and they provide breeding and feeding habitat for numerous endangered bird species. In the $1950 \mathrm{~s}$, there was a break with the traditional production system of the dehesas, caused by a massive emigration of the rural population and a decline of wool price. In spite of this change, livestock husbandry still has an enormous social, economic, and ecological importance. Fifty-three percent of employment in the study area of Cuatro Lugares (province of Cáceres) is in the agricultural sector. However, the dehesa economy is currently challenged by the opening of European markets to the global market. Farmers are re- sponding by forming alliances and by producing goods that stand out against imports. This process could be a chance to combine the goals of secure income maintenance for farmers with those of biodiversity conservation on the rangelands.

To illustrate if and how this could work, we will look at the situation, the problems, and the prospects of sheep husbandry in a rural area of Spain. We the local environment,

- extensive cultivation of fodder

(Figure 3),

- cattle movement from the dehesas to higher elevation pastures in response to the summer periods of forage shortage,

- diversity of land use: animal husbandry with several species of livestock, cultivation of cereals, apiculture, fish farming etc., and

-use of numerous and specialized farm workers like shepherds, sheep shearers, charcoalers etc.

The "crisis of the dehesa" in the 1950s and 60s led to a process of modernization. Farmers shifted to new products, e. g. lamb meat instead of wool or cattle instead of sheep. Production cycles in stockbreeding were accelerated by the cross-breeding of more productive breeds with the indigenous breeds or their complete replacement. Stocking densities were increased. The result was a need for increased external feeding and a higher susceptibility to diseases. Consequently, inputs of energy and nutrients like concentrate fodder, fertilizers, biocides, and veterinary products into the dehesas have increased.

used the area Cuatro Lugares located in the Extremadura region (Figure 2). Its undeveloped landscape is almost completely in use by animal husbandry. Cuatro Lugares ("four places") consists of the four municipalities of Hinojal, Monroy, Santiago del Campo, and Talaván. The climate is semi-arid with a mean annual precipitation of $491 \mathrm{~mm}$. Vegetation consists mainly of open holm oak woodlands (dehesas) and tree-less grain fields, fallows, and pastures (pseudosteppes).

\section{Development of animal husbandry}

Traditionally, land use has been characterized by the following practices:

- use of hardy, indigenous breeds of

livestock that are well adapted to

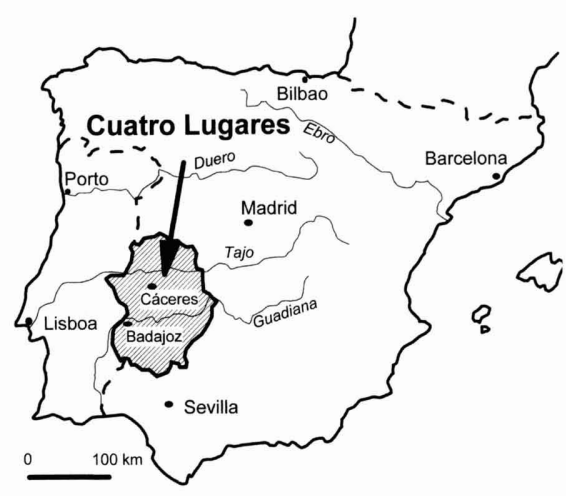

Fig. 2. Location of the study area in the Extremadura region in Spain. 


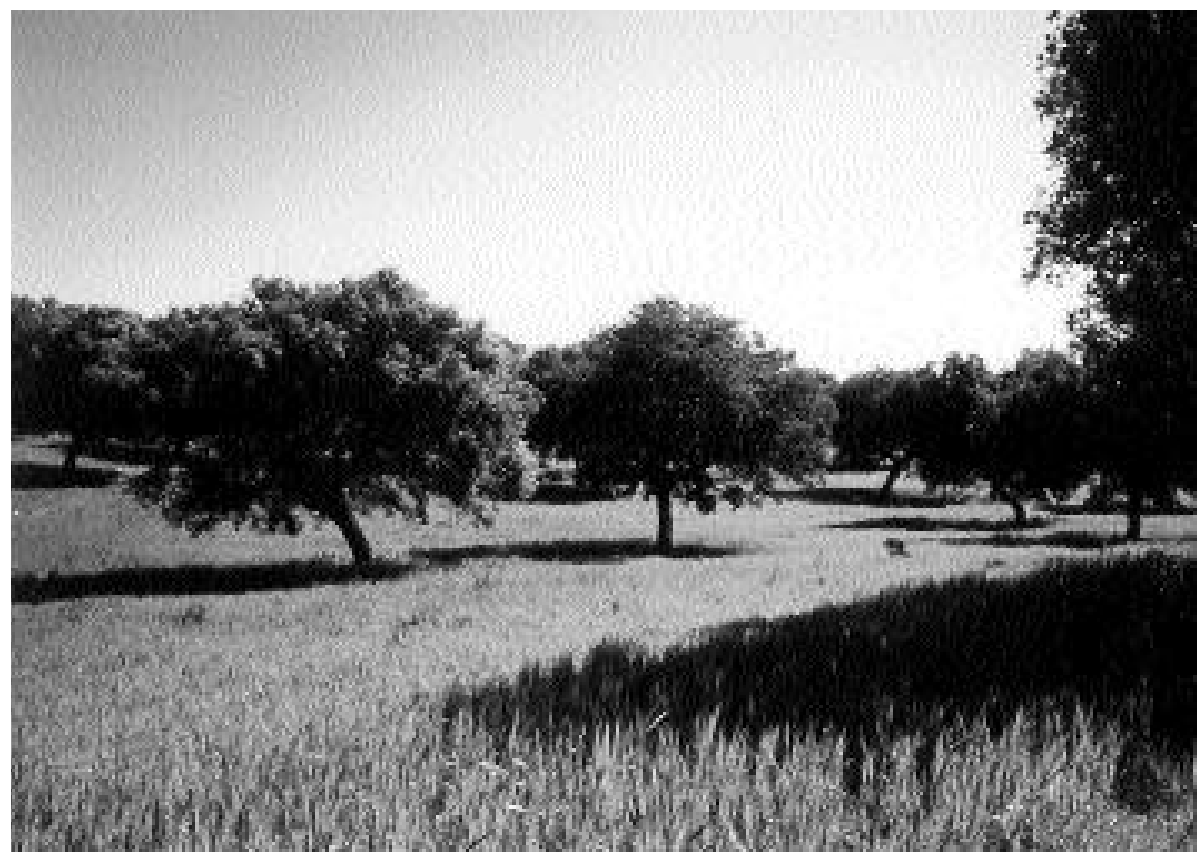

Fig. 3. Extensive fodder cultivation in the dehesas.

\section{Forms of sheep husbandry}

Partitioning of the 554 farms in the study area by size shows $52 \%$ of the farms are small (up to $5 \mathrm{ha}$ ) whereas $20 \%$ of the farms have more than 50 ha of land. Approximately $92 \%$ of the land is in relatively large farms. The smaller farms are operated by the owners and their families who usually do livestock farming as an additional income to other occupations. The owners of the large farms usually do not live on their land. The work on these farms is done by paid employees. The major farm products are milk lambs (corderos lechales) and mast lambs (corderos pascuales). Milk lambs are exclusively fed by milk, while the mast lambs are weaned one month after birth and from then on receive mast fodder concentrate. Other products like adult sheep, wool, and sheep milk have a low market value because they are rarely consumed in Spain. Ewes and bucks are usually kept on the pastures all year round. The lambs are raised in feedlots until they are sold because free-range grazing is considered a decrease of quality. The Spanish market is characterized by a demand for lamb meat with a very bright color. Free-range grazing lambs with their dark red colored meat genes. The aim is to get a better insemination by rut synchronization if the natural breeding attempts are unsatisfactory in spring.

Before the 1950s almost all farm operations moved their sheep to pastures in the mountainous north during the summer drought (Figure 4). Only 100 farms in the whole province of Cáceres realize these livestock movements called transhumance nowadays. The transhumance of livestock today is carried out with trucks. Reasons for the abandonment of the transhumance system are difficulties in finding leasehold land, the progressive destruction of cattle routes due to human development and road construction, and low prices for fodder in comparison to the costs of manpower. Another problem is the lower productivity in the transhumant operation with just one lamb per ewe and year instead of two lambs in three years in the stationary operation.

and their relatively flavored taste are scarcely marketable. Basic nutrition for adult animals is provided by grazing. In summer hay and a mixture of barley, corn, and soy are supplied. The majority of the farms in Cuatro Lugares operate with a reproduction system of three births in two years per ewe. Some farms make use of vaginal sponges impregnated with prosta-

\section{New strategies of income mainte- nance}

Animal husbandry will be exposed to strong competition through meat imports as a result of the planned reduction of trade obstacles in the European Union (EU) in the near fu-

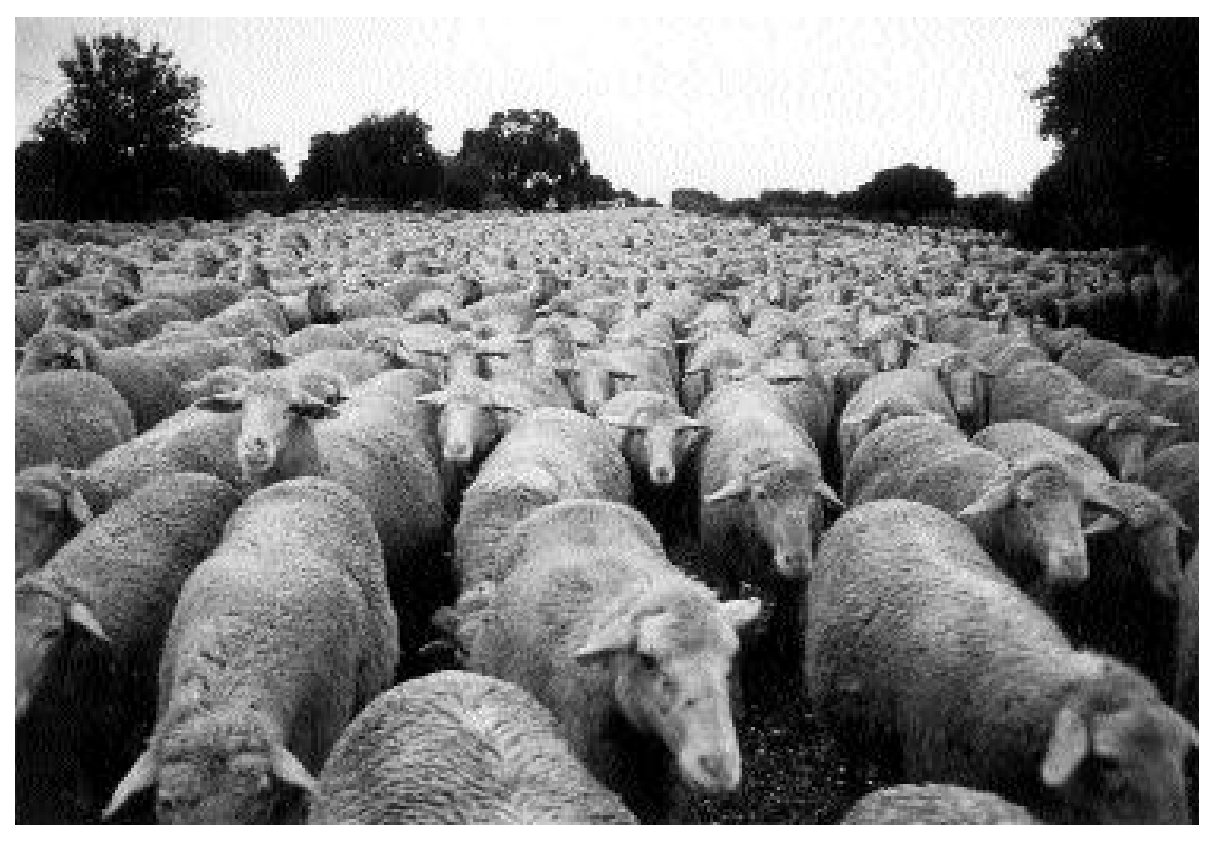

Fig. 4. Merino sheep migrating to their winter pastures in dehesas. 
ture. Even today Spain is a net importer of meat stock and lamb meat from other EU member countries (especially Ireland, Great Britain and the Netherlands) as well as from New Zealand and Argentina. The degree of self-sufficiency has continuously declined in recent years. To stay competitive, sheep farmers in Cuatro Lugares are pursuing two strategies: the organization in cooperatives and the certification of sheep products with quality and origin labels.

\section{Organization in cooperatives}

There are more than 4000 agricultural cooperatives with a total of 2.5 million members in Spain. Within the study area there are two cooperatives of sheep farms. The Cooperativa Cuatro Lugares was founded in 1992 and markets lambs, adult sheep, and wool of 92 enterprises to end-consumers and wholesalers. Cooperative members receive higher prices than by standard marketing strategies. The cooperative buys and delivers approximately 2000 tons of fodder per year to its members at reduced prices. With an average flock size of 500 sheep the cooperative COPRE$\mathrm{CA}^{1}$ is an alliance of the big landowners. Members of the COPRECA sell their products to wholesalers in the Spanish centers of consumption. As another option they can use the cooperative slaughterhouse with a connected carving house in the area of Madrid which sells its lambs directly to the consumer. Moreover the alliance has its own classification center whose objective is the better division of meat stock according to weight, breed, and other quality criteria. As a result, they can guarantee steady quality and realize higher profits.

\section{Quality and origin labels}

Marketing through origin and quality labels is very important in Spain. About $10 \%$ of farm products carry such a label. Criteria are either a defined geographical origin, a special livestock breed or the guarantee of a certain quality. The origin and quality

$\overline{{ }^{1} \text { Corderos Precoces Cácereños (Precocious Lambs of }}$ Caceres)

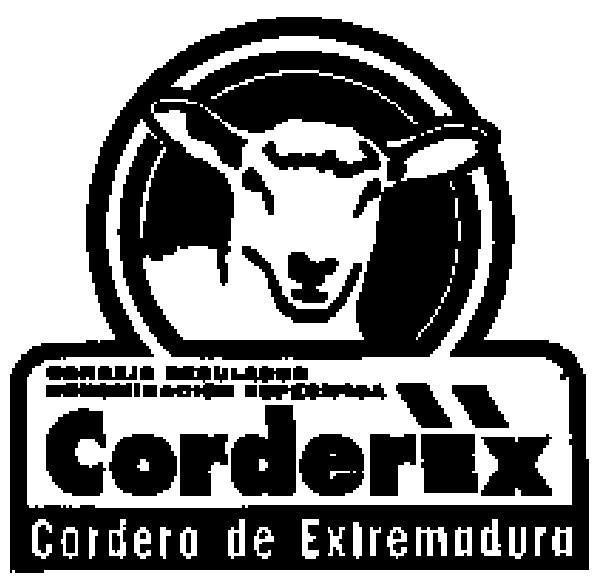

Fig. 5. Quality and origin label CORDEREX.

label CORDEREX ${ }^{2}$ (Figure 5) and the label of certified organic agriculture according to $\mathrm{CEPAE}^{3}$ are an important part of agriculture in the area. CORDEREX requires its members to raise their sheep in Extremadura, to have a base of the indigenous merino breed in the livestock and to slaughter the lambs in Extremadura. Moreover, a string of quality and hygiene criteria during breeding, processing, and storage is required. This label gives a special emphasis to the geographic origin. CORDEREX's aim is to label 15 to $30 \%$ of the mast lambs of Extremadura. Three months after its establishment in 1997 there were more than 500 membership applications from farms. The CEPAE is an institution authorized from the EU to prescribe norms for organic agricultural livestock production. Its most important criteria are the prohibition of permanent stabling, the obligation to use fodder that has been produced according to EU standards for organic agriculture and the prohibition of hormone applications. Supported by the incentive of EU benefits for conversion to organic agriculture, the CEPAE attracted 950 member farms in Extremadura in 1998. However a separate added-value marketing of organically grown food does not yet exist in the area.

New economic orientations in the

\footnotetext{
${ }^{2}$ Cordero de Extremadura (Lamb from Extremadura) ${ }^{3}$ Consejo Extremeño de la Producción Agraria Ecologica (Council of Organic Agricultural Production in Extremadura)
}

area are eco-tourism and hunting. This sector is presently not very important because the visiting season is short, and tourist infrastructure is not well developed. However it is a potentially important area which is currently growing.

\section{Prospects}

The trend to emphasize traditional high-quality farm products typical for the region as a reaction to the economic challenge by the market has so far been successful and has added values to livestock production. Spanish consumers have shown a high readiness to pay increased prices for quality products and regional specialties. As a side effect farmers may be able to get further income through benefits from EU agro-environmental programs by employing traditional practices. These programs are designed to support agricultural production methods that are compatible with protection and improvement of the environment (like organic agriculture or the use of endangered, indigenous breeds). Their importance in the EU's subsidy system is very probable to increase. Traditional husbandry practices can benefit rural tourism as well, because they keep the landscape unique and attractive for visitors.

Potential conflicts with biological conservation in the area are the occasional use of pesticides and mineral fertilizers, high stocking levels, the abandonment of traditional pastoral techniques, and the neglect of the tree layer. The holm oaks are of significant conservation importance but their products like acorns (for hog mast), firewood, and charcoal are not profitable any more. Livestock grazing seems to be a relevant factor of their failing regeneration that threatens the long-term stability of the ecosystem. Credibility and statement of power of existing quality and origin labels like CEPAE or CORDEREX would be strengthened with a stronger consideration of these issues.

At present farmers and members of the environmental community in Cuatro Lugares are trying to bridge the gap between them and to cooper- 
ate closely. Initiatives in other parts of Spain (e.g. in the Valle del Jerte) have shown that an alliance of all local interest groups can advance agriculture, tourism, regional development, and nature conservation likewise. Considering the compatibility of biodiversity conservation and low-input agriculture, the connectedness of local people with dehesas and livestock, and the commitment of farmers and conservationists the requirements for the success of such an alliance in Cuatro Lugares should be met.

\section{Supportive information}

Bartolomé García T.J. 1994. Denominaciones de orígen y de calidad. In: Caja de Badajoz (ed.). La agricultura y la ganadería extremeñas en 1993. Badajoz, Spain. p. 315-332.
Bignal E.M. and D.I. McCracken .1996. Low-intensity farming systems in the conservation of the countryside. Journal of Applied Ecology 33: 413-424.

Díaz M., P. Campos, F.J. Pulido. 1997. The Spanish dehesas: a diversity in landuse and wildlife. In: Pain DJ, Pienkowski MW (eds.). Farming and birds in Europe. San Diego: Academic Press. p. 178-209.

Donoso Caro J. 1994. Cooperativismo agrario. In: Caja de Badajoz (ed.). La agricultura y la ganadería extremeñas en 1993. Badajoz, Spain. p. 353-380.

Joffre R, J. Vacher, C. De los Llanos, G. Long. 1988. The dehesa: An agrosilvopastoral system of the Mediterranean region with special reference to the Sierra Morena area of Spain. Agroforestry Systems 6: 71-96.

Marañón T. 1988. Agro-sylvo-pastoral systems in the Iberian peninsula: Dehesas and montados. Rangelands 10: 255-258.
Pérez Díaz A. 1993. Evolución, dificultades y perspectivas de la ganadería extremeña. In: Asamblea de Extremadura (ed.): Trashumancia y cultura pastoril en Extremadura. Mérida, Spain. p. 183-199.

CORDEREX web site:

www.juntaex.es/consejerias/eic/consejos/ corderex/home.html

LSIRD (Livestock systems in integrated rural development) web site: www.mluri.sari.ac.uk/ mi361/lsird.htm

Authors are graduate students, Institut für Landespflege, Tennenbacher Str. 4, 79106 Freiburg, Germany, e-mail: pliening @ unifreiburg.de (T.P.) and Institut für Forstpolitik, Bertoldstr. 17, 79085 Freiburg, Germany, email: wilbrand@uni-freiburg.de (C.W.)

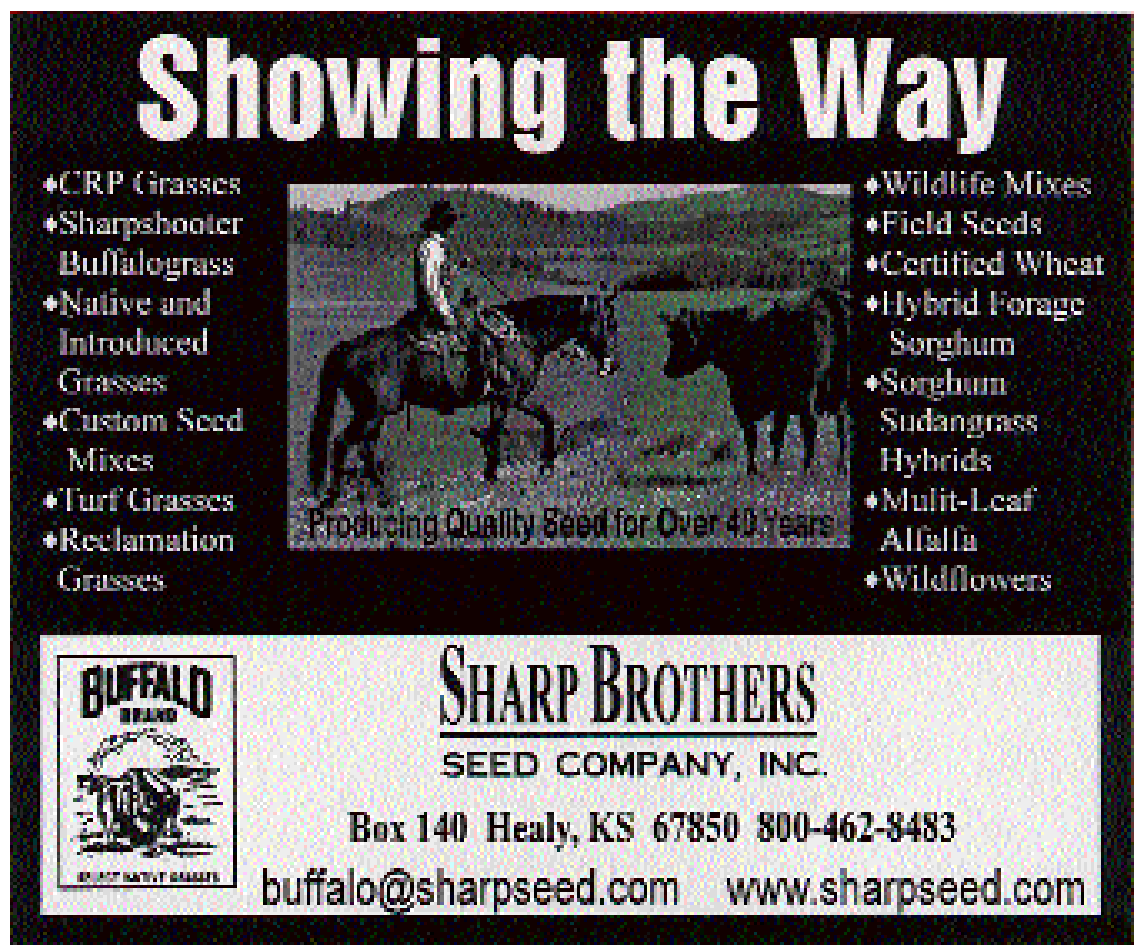

